\title{
Søren Kierkegaard - den nye udgave
}

af seniorforsker, mag.art. Ida Nicolaisen, formand for Søren Kierkegaard Forskningsfonden (foto: Suste Bonnén)

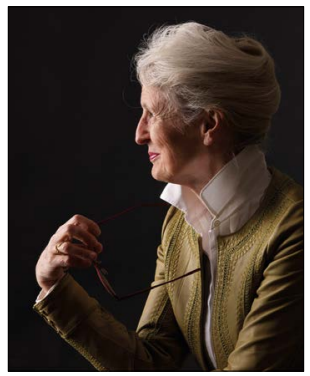

I februar 2013 afsluttedes den hidtil storste

- og eneste - samlede, kommenterede udgave af Søren Kierkegaards (1813-1855) trykte og utrykte skrifter, journaler, notesbøger og løse papirer samt breve og dedikationer efter 18 airs arbejde $i$ det til formàlet af Danmarks Grundforskningsfond i 1994 oprettede Søren Kierkegaard Forskningscenter (SKC), ledet af direktør og dr.theol. Niels Jørgen Cappelørn, der $i 2010$ blev kaldet til et professorat i Kierkegaard-studier samtidig med, at Forskningscenteret blev indlejret $i$ Det Teologiske Fakultet under Københavns Universitet. I 1999 oprettedes Fonden for Søren Kierkegaard Forskningscenteret, der har varet forestaiet af en bestyrelse, ${ }^{1}$ udpeget af Grundforskningsfonden, bvori dekanen for Københavns Universitets Teologiske Fakultet og direktorerne for Det Kongelige Bibliotek og Det Danske Sprog-og Litteraturselskab har varet udpeget.

På Søren Kierkegaards 200 års fodselsdag d. 5. maj afsluttedes Fondens virke med en overdragelse af den trykte udgave af Søren Kierkegaards Skrifter (kaldet SKS-B), der i 55 bind udkom på Gads Forlag 1997-2013, og rettighederne til den til Kobenhavns Universitet og af den elektroniske (kaldet SKS-E), se <sks. dk>, til Det Kongelige Bibliotek. Ved overrakkelsen i Universitetets festsal holdt bestyrelsens formand Ida Nicolaisen nedenstäende overrakkelsestale, der skildrer arbejdet $i$ bistorisk og nutidigt perspektiv.

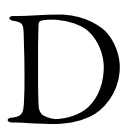
et var en livsnødvendighed for Søren Kierkegaard at skrive, som at trække vejret. "Kun når jeg producerer, befinder jeg mig vel. Da glemmer jeg alle Livets Ubehageligheder, alle Lidelser, da er jeg hos min Tanke og lykkelig." Vi er nok mange, som genkender følelsen, det at være helt væk i et saligt flow, hvad enten vi forsker eller udtrykker os kunstnerisk i form, bevægelse eller farve. "Blot jeg et Par Dage lader det være", skriver Kierkegaard videre, så "bliver jeg straks syg, overvældet, besværet, mit Hoved tungt og betynget”, og - tilføjer han karakteristisk - "en sådan Trang dog vel er et Guds Kald”.

Kierkegaard begynder at skrive relativt tidligt i sit alt for korte liv - kun 42 år blev han. I en alder af 25 år udgiver han sin første publikation med den tankevækkende titel: Af en endnu levendes Papirer, hans analyse og skarpe stillingtagen til bl.a. H.C. Andersens biografiske Kun en Spillemand. Søren Kierkegaard mente, at H.C. Andersen ikke ejede 'livsanskuelse' - en overordnet gennemtænkning af livets vilkår. "Andersen kan skrive om Lykkens Galocher, men jeg kan skrive om Skoen der trykker", som han siger. Og det sidste kunne Søren Kierkegaard om nogen.

Tre år efter udgivelsen af Af en endnu levendes Papirer bliver Kierkegaard ma- 


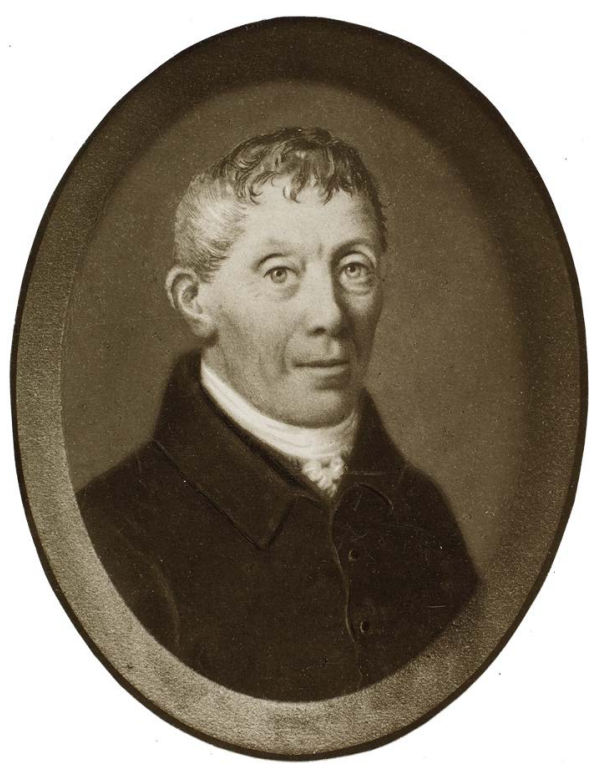

Faderen M.P. Kierkegaard (1756-1838) voksede op som fattig hyrdedreng på den jyske hede men kunne - takket vare et helt sorligt handelstalent - allerede $i$ en alder af 40 ar trakke sig tilbage og leve som rentier $i$ København. Ud over at gøre uld til guld drev han også boligspekulation.

gister på værket Begrebet Ironi. Det er på dette tidspunkt, han overvejer at forlove sig med den ni år yngre Regine Olsen. Men inden da drager han til Jylland for at få klarhed over sine tanker, nærmere betegnet til sin fars fattige fødegård i Sædding, hvor han mente, at slægtens skæbne var blevet beseglet. For det var her på heden, at Michael Pedersen Kierkegaard som lille 10-årig hyrdedreng forbandede Gud under et forskrækkeligt tordenvejr, en gerning han til sin dødsdag angrede og troede, at han ville blive straffet for ved at skulle overleve sine syv børn. Fem af Søren Kierkegaards søskende er allerede gået bort på dette tidspunkt, og da han som nævnt deler faderens tro på profe- tien, rejser det at indgå ægteskab alvorlige etiske og trosmæssige spørgsmål. Efter tilsyneladende at have nået til klarhed, forlover Kierkegaard sig dog snart efter hjemkomsten med den attråede, blot for at bryde forbindelsen til den evigt elskede kun et år senere. Regine forlover sig med Fritz Schlegel og følger senere med sin mand til Dansk Vestindien, hvor han er guvernør i årene 1855-60. Det er her, hun modtager besked om Søren Kierkegaards død og meddelelse om, at hun er hans arving. Efter bruddet med Regine, som sætter varige spor i Søren Kierkegaards sind, slikker han sine sår og kaster sig derpå ind i forfattervirket, som den ildsjæl han er. Gennem en kolossal arbejdsindsats udgiver han ikke mindre end 40 bogtitler og et tilsvarende antal dagbladsartikler i løbet af de næste syv-otte år, den periode som omfatter hans centrale forfatterskab.

\section{Forfattervirksomheden}

Søren Kierkegaards far havde arbejdet sig ud af fattigdommen og var blevet en velhavende hosekræmmer med bolig på Nytorv. Det var her, Søren voksede op, og faderens formue, som var betydelig, tillod ham at bo i egne komfortable lejligheder, spise på restaurant og gå i Det Kongelige Teater som han havde lyst, ofte med sin eneste nære ven Emil Boesen. Men med forbandelsen hængende over hovedet var han sig pinefuldt bevidst, at hans tid på jorden var smertelig beskåren, at tiden var kostbar. Efter kandidatgraden sporer Kierkegaard derfor hele sit formidable intellekt ind på at udforske og afklare de grundlæggende spørgsmål, som vi hver især må forholde os til, hvis vi vil tage vare på vores liv: spørgsmål om etik, om at gøre det gode, som evangelisten Matthæus beskriver i kapitel 22 vers 39, om at vise 
kærlighed og omsorg for næsten, ansvar for det fællesskab, vi er en del af; såvel som spørgsmål om tro, vores forhold til Gud og de dilemmaer, som forskellige livsholdninger stiller os overfor.

I denne første del af forfatterskabet den 'opbyggelige' - finder vi de omfattende filosofiske og psykologiske værker, alle skrevet under pseudonym og med sikker stilistisk pen. På kun tre år, fra 1843 til 1846, skriver og udgiver Søren Kierkegaard først Enten-Eller, som han forfattede i Berlin efter bruddet med Regine - dette kompliceret skrevne værk, som blandt andet rummer Forforerens Dagbog om en psykologisk raffineret æstetikers kyniske forførelse af den unge Cordelia, en forførelse som i sidste ende bunder $i$ hans angst for at stå ved, hvem han er. Kierkegaard skriver her om følelsesmæssig splittelse, erkendelse og ansvar i form af en brevveksling mellem æstetikeren Johannes, som bruger list, fantasi og ironi til at lokke Cordelia og dermed skaffe sig tilfredsstillelse, fordi det for ham ikke er akten, men selve forførelsen, som er drivkraften, medens etikeren assessor Wilhelm i sine overvejelser forfægter det etiske valg og ægteskabet, et valg som indebærer, at vi ikke blot vælger det gode, men dermed også forskellen mellem godt og ondt.

Det etiske valg er ensbetydende med at 'vælge sig selv', som Kierkegaard ser det, ensbetydende med at tage ansvar ikke blot for, hvad vi gør, men også for den historie, det forløb gennem hvilket vi er blevet til den, vi er, hver især. Andre kan ikke leve vores liv for os, vi må selv vælge bevidst og ansvarligt. Vi må vedkende os som det menneske, vi er, denne 'hin enkelte', $i$ både etisk og religiøs forstand, for det er et grundlæggende livsvilkår, siger Kierke- gaard, et vilkår, som han kredser om og uddyber videre i påfølgende skrifter.

Inden for de samme tre år skriver Kierkegaard yderligere sine seks samlinger med $i$ alt atten opbyggelige taler samt værkerne Gjentagelsen, Frygt og Beven, Philosophiske Smuler, og Begrebet Angest, hans eminente psykologiske analyse af det indestængte i os mennesker, den indre dæmoni, som vi nødvendigvis må få ud i lyset og erkendt, for at vi kan blive os selv. Når vi ikke lykkes hermed, siger Kierkegaard, er det ikke blot af angst for det onde, men også for det gode. Vi lever i en slags selvskabt ufrihed, som vi ikke er i stand til at befri os for, men kun kan komme ud af ved at ty til Gud.

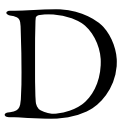
enne imponerende indsats sker samtidig med, at Kierkegaard er udsat for angreb. I 1845 havde P.S. Møller trykt et stærkt personligt angreb på Kierkegaard i tidsskriftet Gra, Asthetisk Aarbog, et angreb som blev startskuddet på fejden i Meïr Aron Goldschmidts Corsaren og de berygtede karikaturtegninger. Det var en strid, som tog hårdt på Kierkegaard, ikke mindst fordi hans Enten-Eller var blevet modtaget meget fint af Goldschmidt. Nu måtte han så se sig pillet ned af piedestalen og blive gjort til grin i offentligheden, hvor han hidtil var blevet hyldet.

På trods af disse vanskeligheder når Kierkegaard alligevel også i disse få år at skrive Forord, Tre Taler ved tankte Leiligheder samt Stadier paa Livets Vei, hvori han igen belyser den komplicerede rejse, som menneskelivet er, og igen diskuterer æstetikerens og etikerens dilemmaer. Endelig udgiver han et 600 siders Afsluttende uvidenskabelig Efterskrift til de philosophiske Smuler, hvori han vedkender sig de 
pseudonymer, han har skrevet under og præciserer sin forståelse af troens vilkår og eksistensbegrebet.

Det var Kierkegaards hensigt hermed at sætte et endeligt punktum for forfattervirksomheden. I 1846 vil han fylde 33 år, hans skæbneår. For Kierkegaard tror ikke blot, at han skal dø ung, men er af den faste overbevisning, at han ligesom Jesus kun skal blive netop 33 på grund af den Guds forbandelse, som hviler over den Kierkegaardske familie. Kun hans ældre broder Peter Christian er ligesom han endnu i de levendes land.

S kæbnen vil det imidlertid anderledes. Kierkegaard må indstille sig på, at han fortsat er i live, og han fordyber sig nu yderligere i studiet af det kristelige, i spørgsmål om inderliggørelse og opvækkelse. Fra 1847 og indtil 1851 - en periode hvor han i øvrigt er plaget af sygdom - udgiver han To Taler ved Altergang om Fredagen og værkerne Kjerlighedens Gjerninger, Opbyggelige Taler i forskjellig Aand, Christelige Taler, Lilien paa Marken og Fuglen under Himlen, Sygdommen til Døden, samt Indøvelse i Christendom. Sideløbende hermed nedfælder Kierkegaard sine tanker i journaler og notesbøger. Det blev til ikke mindre end 36 bind, som han nummererede fortløbende, formentlig for at de kunne tjene som referencesystem.

\section{Kirkekampen}

I 1854, året før Søren Kierkegaard dør, kaster han sig ind i et brændende opgør med kirken som institution, i en kamp for en ægte kristendom, som for ham er et forhold mellem den enkelte og Gud befriet for alt overformynderi. Han kommer med sine angreb i flyvebladet
Øieblikket (udgivet nr. 1-10), som han selv finansierer og sender på gaden. For Kierkegaard drejer opgøret sig om 'Redelighed', om hvorvidt kristendommen er for alle, eller om nogle har speciel adgang til troen. Klar i argumentationen og med sin sylespidse, meget vittige pen går han i åben polemik om kirkens rolle og hvem, den skal tjene efter Grundloven af 1849 , hvor enevælden udskiftes med demokrati. Kierkegaard stiller skarpt på, hvad det indebærer at være kristen og at være en kirke. Provokeret af den intellektuelle, Hegel-inspirerede hofprædikant, Hans Martensens gravtale over biskop J.P. Mynster, hvori han kaldte den afdøde for et 'Sandhedsvidne', går Kierkegaard i kødet på det verdsliggjorte præsteskab og opfordrer folk til at boykotte kirken. Overskriften på et af hans sidste indlæg 'Tag et Bræk-Middel' anslår tonen.

Kierkegaard rejser spørgsmålet, om kirken har været tro imod den sandhed, den er forpligtet på, nemlig forkyndelsen. Præsterne skal henvende sig til hver og én af os, hvor vi end befinder os, siger Kierkegaard. De skal forkynde, at vi er Guds skabninger, at der er forskel på godt og ondt, og at "hvert Menneske (er) evigt ansvarlig for hver Time han lever, end det mindste han foretager sig, thi det er Christendom." Han angriber kirken for at forfladige dette budskab og for at gøre denne til en tam statsinstitution: "I det nye Testamente fremstiller Verdens Frelser, vor Herre Jesus Christus Sagen saaledes: Veien, som fører til Livet, er trang, Porten snever - Faa de som finde den. - Nu derimod er for blot at blive ved Danmark, vi Alle Christne, Veien saa bred som vel mulig, den bredeste i Danmark, da det er den vi alle gaae ad, derhos i alle Maader beqvem, comfortabel, og Porten 
saa viid som det er muligt, videre kan jo dog en Port ikke være, end den gjennem hvilken Alle gaae en masse: ergo er det nye Testamente ikke mere Sandhed." Eller som Kierkegaard skriver et andet sted om kirken: "Enhver der deeltager, deeltager $i$ at lege Christendom og i at holde Gud for nar."

Det var et angreb, der ville noget. Med udsagn som ovennævnte og andre lignende som f.eks. , at 'Kristendommen blev afskaffet i takt med dens Udbredelse' samt hans kanonader mod præsterne for at hytte deres eget $i$ stedet for at forkynde, blev Kierkegaard det store samtaleemne i Kongens København og gav startskuddet til heftige diskussioner af kirkens rolle og til selvkritik inden for denne. Kampen var imidlertid opslidende. I oktober 1855 bringes Kierkegaard dødssyg til Frederiks Hospital, det nuværende Designmuseum Danmark. Her dør han en måneds tid senere den 11. november. Han begraves fra en stuvende fuld Domkirke, den han selv havde hørt til, og hans kiste førtes derpå til familiegravstedet på Assistens Kirkegaard fulgt af en tusindtallig skare af borgere og fattiglemmer.

\section{Tidligere udgivelser}

De fleste af Kierkegaards bøger kom i et oplag på 500, Begrebet Angest dog kun i 250. Mange solgte ikke særlig godt. Kierkegaard havde således langt fra den læserskare, han kunne ønske sig og mente sig fortjent til. Og der kom ikke flere til lige efter hans død i 1855.

Først i 1879, hele 25 år efter Kierkegaards død, vækkes interessen igen med Georg Brandes biografi Søren Kierkegaard. Den voksede støt omkring århundredskiftet og førte til den første af de i alt tre udgivelser af Søren Kierkegaards Sam- lede Værker indtil den nye, vi nu har adgang til. Den første kom i 1901-06. Den var på fjorten bind og omtaltes af de tre redaktører A.B. Drachmann, J.L. Heiberg og H.O. Lange som en 'folkeudgave'. De fulgte arbejdet op i 1920-36 med en mere videnskabelig udgave på $\mathrm{i}$ alt 15 bind som inkluderede et sags- og forfatterregister og en terminologisk ordbog. Dette værk blev sat med fraktur eller gotisk skrift, og det blev derfor uanvendeligt i takt med, at evnen til at læse 'krøllede bogstaver', som de kaldtes i min skoletid, mindskedes. Gyldendal besluttede derfor at lade Peter P. Rohde redigere en billigbogsudgave i 20 bind. Den kom i 1962-64.

I 1909 havde P.A. Heiberg og V. Kuhr taget initiativ til en stort anlagt udgave af Søren Kierkegaards Papirer, men det viste sig hurtigt, at de havde slået for stort et brød op, så man endte med et vist udvalg af forarbejderne, notater fra bøger og forelæsninger, medens breve og biografiske dokumenter ikke kom med. Udgaven er på 20 bind, reelt dog kun 11, da nogle er delbind. De suppleredes i 1948 med to bind med de manglende notater og langt senere med Niels Jørgen Cappelørns værdifulde indeks på tre bind. I 1980'erne overvejede Kierkegaard Selskabet en ny udgivelse af skrifterne, men opgav på grund af forskellige vanskeligheder.

\section{Søren Kierkegaard Forskningscenteret} Én person brændte imidlertid for en ny udgivelse af Søren Kierkegaards livsværk og havde samtidig forståelse for, at der var behov for en helt anderledes form for udgave, og det var professor Niels Jørgen Cappelørn. Han indså, at det var på tide at gøre vor store filosof tilgængelig både herhjemme og globalt, og at en ny udgave skulle tjene ikke blot forskere, men også 


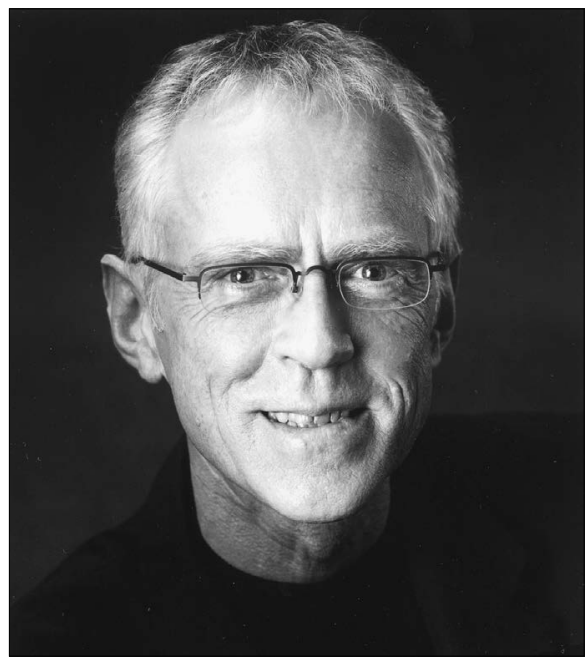

Niels Jorgen Cappelorn (f. 1945) var tidligere generalsekreter for Det danske Bibelselskab inden han i 1994 tog initiativet til oprettelsen af Søren Kierkegaard Forskningscenteret og den store udgave af skrifterne (foto: Rigmor Mydtskov).

en bredere kreds med interesse for det Kierkegaard'ske univers. Der skulle skabes en tværfaglig, forskningsbaseret, bredt kommenteret udgave, hvor værkerne sattes ind i en kontekst. Det var denne vision, Niels Jørgen Cappelørn forelagde for Danmarks Grundforskningsfond, og i 1994 oprettedes så Center for Søren Kierkegaard Forskning som et 'Center of Excellence' for at omsætte den til virkelighed. I dag kan vi glæde os over resultatet, som på smukkeste vis opfylder, ja så langt overgår, hvad der oprindeligt var hensigten med denne: nemlig dels at varetage og fremme Kierkegaard-forskningen nationalt og internationalt, dels at tilvejebringe en komplet, tekstkritisk, kommenteret udgave af alt, hvad der er overleveret fra Søren Kierkegaards hånd under titlen Søren Kierkegaards Skrifter.

\section{Forskningen}

Kort tid efter oprettelsen var der skabt et levende, tværfagligt forskningsmiljø på centeret, befolket af et mylder af danske og internationale forskere - flere hundrede er det blevet til gennem årene. Mere end 100 ph.d.-studerende har hentet inspiration, fået vejledning og deltaget $\mathrm{i}$ de ugentlige forskerseminarer i lokalerne i Vartov. Der er afholdt 15 internationale konferencer, som alle er publiceret i Centerets Monograph Series; den første om Kierkegaard and the Meaning of Meaning blev gennemført året efter startskuddet. Siden er det gået slag i slag med at belyse nye forskningstemaer, som: Kierkegaard und Schelling (Vol. 8); Kierkegaard and his Contemporaries (Vol. 10); Schleiermacher und Kierkegaard (Vol. 11); Kierkegaard und Fichte (Vol. 22); Schopenhauer - Kierkegaard (Vol. 26) etc. Centeret har endvidere udgivet en årlig Yearbook med peer-reviewed artikler; de ansatte forskere har skrevet doktordisputatser, en af dem endda hele to, og der er blevet skrevet og redigeret bøger, antologier og artikler en masse, også på dansk. Man kunne frygte, at Centerets forskere med dette arbejdspres lukkede af for offentligheden, men det modsatte har nærmest været tilfældet. De har i alle år formået at formidle Kierkegaards tanker og bringe deres forskning om ham i spil sideløbende med det imponerende forsknings- og udgivelsesarbejde. Det er sket gennem mere populærvidenskabelige bøger, udgivet dels af Søren Kierkegaard Centeret (SKC), dels af Gyldendal og andre forlag, ligesom de har holdt foredrag og deltaget i og selv skabt debatter og optrådt i medierne, så ingen kunne være i tvivl om, at der var gang i Kierkegaardforskningen. 


\section{Søren Kierkegaards Skrifter}

Den anden del af SKC's virke, den som primært var anledningen til Centerets oprettelse, og dermed årsagen til, at jeg står på Universitetets talerstol i dag på Søren Kierkegaards 200-års fødselsdag, var som nævnt at publicere en samlet forskningsbaseret og kommenteret udgave af alle Søren Kierkegaards nedfældede tanker - de udgivne bøger og skrifter, såvel som færdige og ufuldendte værker, journaler, notesbøger, breve, dagbladsindlæg, flyveblade, biografiske dokumenter og løse papirer. En gigantisk opgave, som er lykkedes takket være et eminent forskerteam og støtte fra mere end to hundrede forskere fra hele kloden. Resultatet er en færdig udgave på hele 28 tekstbind og 27 kommentarbind, så smukt sat og trykt at de har været udvalgt som kandidat til prisen 'Årets bedste bogarbejde’ af Forening for Boghaandværk. Kommentarbindene indeholder over 72.000 noter til belysning af, hvor Søren Kierkegaard hentede inspiration til sine intellektuelle byggeklodser og af hvordan han blev påvirket af andre filosoffers og teologers tanker, samtidens debatter, politiske begivenheder, sociale tilstande og kirkens koryfæer og ageren i samfundet.

Udgangspunktet for den nye udgave af Søren Kierkegaards livsværk har været at se dette som en helhed og ikke forlods foretage en opdeling mellem udgivne og uudgivne tekster, mellem skrifter og journaler, sådan som tidligere udgaver har gjort. Dette er et nybrud i pagt med Kierkegaards egen måde at arbejde på og hans udsagn, at livet "leves forlæns men forstås baglæns”, forstået på den måde, at journalerne belyser de tanker, Kierkegaard gjorde sig i løbet af arbejdet. De er Kierkegaards mentale værksted, så at sige, medens skrifterne er der, hvor tankerne finder et endeligt udtryk. Kierkegaard brugte selv billedet, at 'øvelsen sker i kulissen', inden der trædes frem for offentligheden på scenen. Eller sagt på anden vis: I journalerne søger Søren at formulere sine tanker om det levede liv, medens skrifterne indeholder hans refleksioner herover eller måske lidt spidsfindigt reflekterer hans refleksioner.

Denne tilgang og forskernes stræben efter at være så tro som muligt mod værket og Kierkegaards arbejdsform, hans brug af henvisninger og citater etc. afspejler sig i tilrettelæggelsen af bøgerne. Den dokumenterer, hvem der senere var inde over Kierkegaards manuskripter. Gennem samarbejde med Dansk Teknologisk Institut og brug af avanceret elektron- og lysmikroskopi af det anvendte blæks kemiske grundbestanddele, har det været muligt at vise, om rettelser og tilføjelser i manuskripter og udgaver er foretaget af Kierkegaard selv, hans bror eller andre. Det er en metode, som andre udgivelser siden har taget til sig, bl.a. Carl Nielsen Udgaven på Det Kongelige Bibliotek. Der er også udviklet speciel software til serien. Den muliggør en kodning af teksterne således, at de trykkes på identisk vis på de mange andre sprog, Søren Kierkegaards Skrifter udkommer på. Udgaven har derfor sat en ny editionsfilologisk standard, som allerede har været til inspiration eller det direkte forlæg for udenlandske udgaver, blandt andet af Henrik Ibsens samlede værker i Norge. Ifølge direktøren for dette projekt, professor Vigdís Ystad, havde det ikke været muligt at gennemføre denne opgave uden brug af forlæg fra Søren Kierkegaard Udgaven og støtte fra Centeret. 


\section{Kommentering}

Kommentarerne er et kapitel for sig. De omfatter som nævnt hele 27 bind med over 72.000 indgange. Er det for mange? Er noteapparatet for stort, vil nogle måske spørge? Tætheden er imidlertid ikke grebet ud af luften. Der er tænkt grundigt over hvilket niveau, der skulle vælges, så ikke blot Kierkegaard-forskere og -fans kunne bruge værket, men tillige studerende og den interesserede lægmand - også i udlandet. Der var mange overvejelser. Hvad var det f.eks. nødvendigt at skrive om Guldaldertidens København og persongalleri? Hvilke udtryk er gledet ud af almindelig dansk sprogbrug siden Kierkegaards tid eller har antaget en anden betydning? Og hvad med bibelkundskaberne? Hvad er generel viden i dag? For at finde niveauet gav man først en række danskstuderende ved Universitetet i Odense nogle af Kierkegaards tekster og lod dem strege ind, hvad de ikke forstod eller kendte til. Siden tog man så bestik af de mange andre forhold, som skulle tages i betragtning.

Selve kommentarerne har også krævet stor ekspertise. De forudsætter kendskab ikke blot til Søren Kierkegaards værker, men også til, hvad han havde læst - og dermed til de mange sprog, han benyttede sig af: Biblens græske og hebraiske foruden til latin, fransk og tysk - såvel som til det, der optog ham, hvad der rørte sig i Dannevang og Udenlands, avisernes daglige beretninger etc. Det er ikke blot noget, man lige gør, det med at skrive noter, selv som ekspert på feltet. Jeg erindrer, at Niels Jørgen Cappelørn en sen aften peb lidt over besværet med endnu en genstridig kommentar på nogle få linjer. Den havde krævet mere end femhundrede opslag ikke blot i værker, som Kierkegaard selv ejede (et bibliotek, som Centeret i øvrigt har genskabt for at have nem og hurtig adgang til kilderne), men en tidskrævende gennemtrawling af datidens aviser og andre kilder på Det Kongelige Bibliotek. Femhundrede opslag, det skulle der til for at sætte spørgsmålet ind i den rette kontekst og forklare, hvorfor i alverden Søren Kierkegaard kom med den givne betragtning.

\section{Online og internationale udgivelser} Det har fra dag ét været et mål, at hele værket også skulle være tilgængeligt på nettet med et udbygget søgesystem. I takt med, at værkerne er udgivet i bogform, er de derfor også kommet i en elektronisk udgave. Denne er nu af Søren Kierkegaard Forskningsfonden overdraget til Det Kongelige Bibliotek og med støtte fra Augustinus Fonden indpasset i bibliotekets system. Her er den i de bedste hænder og vil løbende blive opdateret i takt med den nyeste forskning, således at udgaven ikke forældes. Fonden har endvidere sikret udgivelser på forlag verden over, hvor der er stor interesse for Søren Kierkegaards Skrifter. Foreløbig kommer dele af udgaven på ikke mindre end 14 sprog i USA, Frankrig, Tyskland, Kina, Polen og Ungarn o.a. altid i tæt samarbejde med Centerets forskere. Enkelte skrifter udgives også på finsk, svensk, norsk, italiensk, portugisisk og rumænsk, og der har været henvendelse om oversættelser på bl.a. persisk og arabisk - alt sammen i pagt med Fondens formål, som er at sikre internationalisering af dansk forskning. Endelig er der lavet en aftale med Gyldendal om udgivelse af en 15 binds billigudgave. I dag, hvor den nye udgave er færdig og de mange internationale udgivelser godt på vej, er det mig en stor glæde endnu engang 


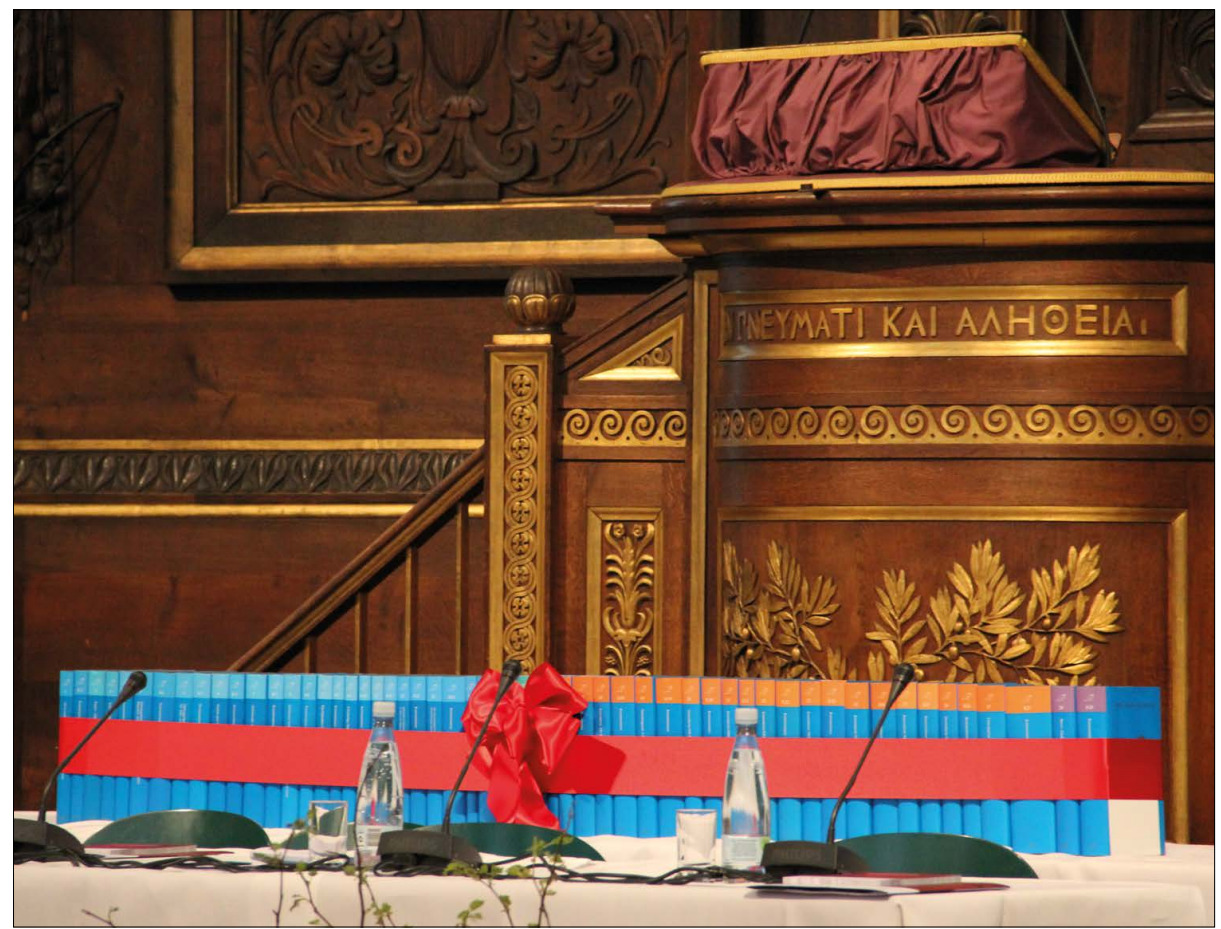

Udgaven i al sin pragt: De tilsammen 55 bind stillet op $i$ Universitetes festsal i forbindelse med overdragelsen den 2. maj (foto: Søren Kierkegaard Forskningscenteret).

at kunne takke den fond og de ministerier, som primært har støttet arbejdet: Først Grundforskningsfonden, som søsatte projektet, og siden Ministeriet for Videnskab, Teknologi og Udvikling og Kulturministeriet, som har gjort det muligt at afslutte dette, Danmarks største humanistiske forskningsprojekt til dato.

\section{Interessen for Kierkegaard}

Kierkegaard er 'in', herhjemme og i verden omkring os, ingen tvivl om det. I år sætter fejringen af Sørens fødselsdag den 5. maj sammen med de mange bogudgivelser, avisomtaler, radio- og TV-indslag og udstillinger naturligvis turbo på interessen. Men den er reel og voksende. For en antropolog er det nærliggende at se denne vækst i sammenhæng med ændringerne i samfundet: den ekstremt hurtige teknologiske udvikling, vi står midt i, og de omstillingsprocesser, som følger i kølvandet herpå af økonomisk, social, kulturel og værdimæssig art, processer som påvirker os fundamentalt som mennesker. Der sættes nye rammer for den enkeltes liv, ansvar og mulighed for at udtrykke sig. Forholdet mellem individ og samfund er til debat, tænk blot på brydningerne for øjeblikket i Ægypten, Bahrain, Tunesien, Tyrkiet og andre lande i Mellemøsten, eller på hvorledes mobiltelefon, internet, og sociale medier som Facebook og Twitter nu skaber og definerer kommunikation 
mennesker og lande imellem, åbner op for nye netværk, for uddannelse, for at hidtil isolerede individer og grupper kan få information, de politisk undertrykte ytre sig; men også på, hvorledes den ny teknologi nu anvendes til overvågning og undertrykkelse fra statslige efterretningssystemer og hvordan bitte små 'hummingbirds' måske snart summer rundt alle vegne og fortæller andre, hvad vi foretager os bag lukkede døre.

Som en konsekvens af opbruddet, mængden af informationer og den hast, med hvilken de vælter ind over os, kompleksiteten i holdninger, vi konfronteres med og skal forholde os til, er vi i disse år ekstremt interesserede $i$ autenticitet, $i$ at finde os selv i en verden, hvor alt synes til forhandling. Coaching har kronede dage, det samme har buddhistisk inspirerede terapier som mindfulness og mange andre. Livsstilsmagasinernes glittede sider lokker os til at tro, at vi ikke blot kan signalere vores identitet, men derigennem, på nærmest magisk vis, finde os selv gennem indretning af vore boliger, brug af kultur, mode, tatoveringer og hvad ved jeg. Vi vil så gerne dette med at 'vælge os selv', men har svært ved andet end at halse af sted i vores søgen, hvor vi skulle stoppe op for at se indad og give os tid til erkendelsesprocessen.

Søren Kierkegaard var 'på forkant' med de spørgsmål, som er påtrængende for os i dag. Han har skrevet om angsten, som er et menneskeligt grundvilkår, har vendt og drejet spørgsmål om ansvar, om at stå ved egne handlinger. Han har skrevet om den proces, gennem hvilken vi hver især bliver til den, vi er, og om de etiske valg, vi er nødt til at træffe. $\mathrm{Nu}$ ligger hans tanker tilgængelige for alle, der vil dem: for forskere og de, som vil skrive mere populært om Kierkegaard og formidle hans tanker, for kunstnere som vil hente inspiration og for alle os andre, når vi har behov for at tænke dybere over tilværelsens store spørgsmål, vort sinds krinkelkroge, og de valg, vi skal eller måske bør træffe.

I 2010 indlejredes Søren Kierkegaard Forskningscenteret i Københavns Universitet med en stab af kyndige forskere: Niels Jørgen Cappelørn, Joakim Garff, Jon Stewart og Pia Søltoft. Endvidere knyttedes et vækstlag af unge ph.d.studerende til Centeret for at sikre, at Københavns Universitet efter den store forskningsindsats fortsat kan fungere som det internationale center for Kierkegaardforskning. I dag har jeg så den glæde at kunne overdrage de 55 raffinerede blå bind til Københavns Universitet og dermed afslutte Søren Kierkegaard Forskningsfondens opgave. Med gaven følger et pænt beløb og rettighederne til royalties fra udgivelsen og den kommende billigbogsudgave, således at udsolgte bind kan genoptrykkes efter behov, og at der vil være støtte til de udenlandske udgivelser, som stadig er på bedding, og de nye, som kommer til. Pas godt på Centeret og dets levende, internationale forskningsmiljø og pas på Udgaven - Universitetet får den på et sølvfad. Held og lykke. 


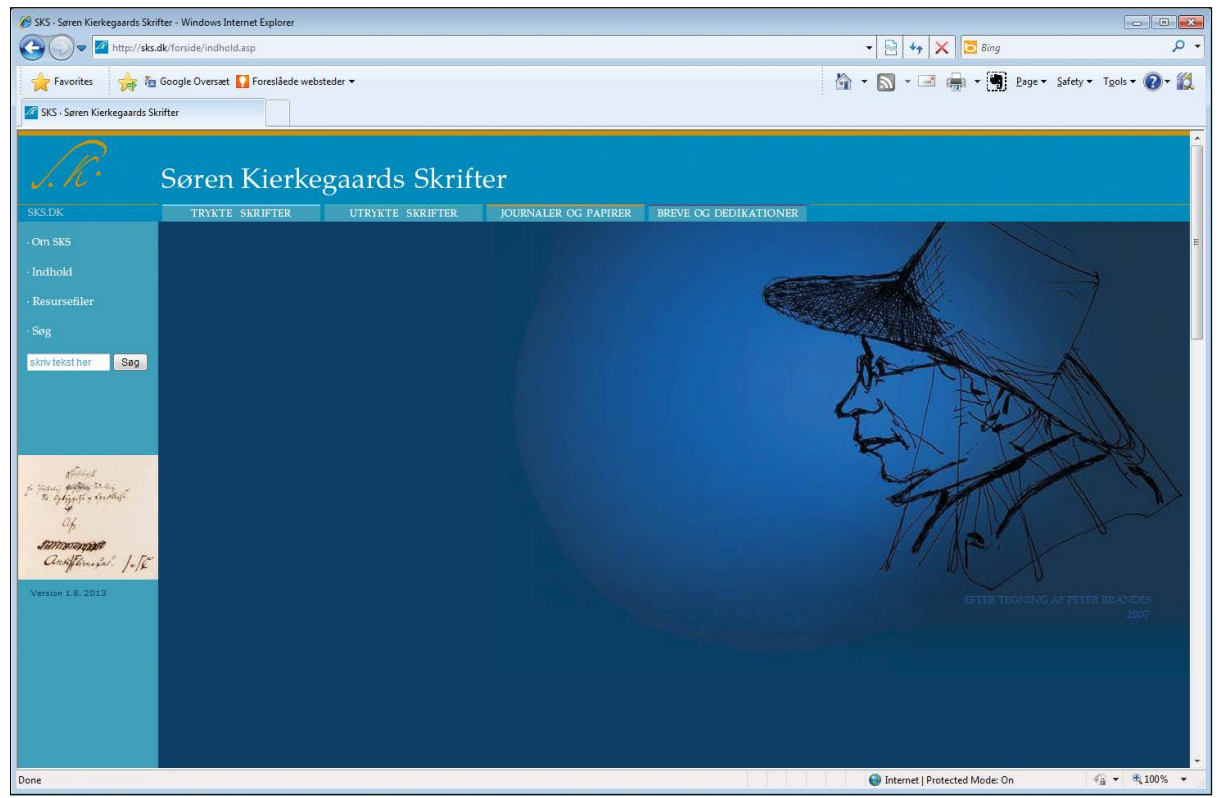

Screen dump fra SKS-E - den elektroniske udgave af Søren Kierkegaards Skrifter. Her kan enhver gratis på på opdagelse i både trykte og utrykte varker.

\section{Udvalgt litteratur:}

Cappelørn, Niels Jørgen, Gert Posselt \& Bent Rhode: Tekstspejle. Om Søren Kierkegaard som bogtilrettelagger, bogudgiver og bogsamler. Rosendals Forlag, 2002.

Centres of Excellence i 10 år. Danmarks Grundforskningsfond, 2003.

Cappelørn, Niels Jørgen \& Bent Rohde: Fra Fraktur til Palatino. Søren Kierkegaards Skrifter. K1 Sertryk. Gads Forlag, 1997.

Garff, Joakim: At komme til sig selv. 15 portratter af danske dannelsestonkere. Gads Forlag, 2008.

Nørregaard-Nielsen, Hans Edvard: Gyldne Dage og Morke Natter. Omkring Kongens Nytorv. Gyldendal, 1994.

Stewart, Jon: Danish Golden Age Studies (5 bd.). Museum Tusculanum, 2007-2008.

Tullberg, Steen: Søren Kierkegaard i Danmark. En receptionshistorie. Søren Kierkegaard Forskningscenteret, 2006.
Søren Kierkegaards Skrifter. [Skrifter og papirer:] Bind 1-28 \& [Kommentarer:] Bind K1-27. Gads Forlag, 1997-2013. Digital udgave: <sks. dk>

SKS - Interne papirer. Søren Kierkegaard Forskningscenteret, 2013.

“Søren Kierkegaard”, I: Den store danske Encyklopadi. Gyldendal 1994-2001, og I: Wikipedia. Den frie Encyklopedi

\section{Noter}

1 Bestyrelsen bestod ved Fondens nedlæggelse af seniorforsker Ida Nicolaisen (formand), tidl. adm. direktør Hans Skov Christensen (næstformand), dekan, professor, dr. theol. Steffen KjeldgaardPedersen, direktør, adj. professor Erland Kolding Nielsen og tidl. direktør, professor Jørn Lund.

2 (Pap. VII 1 A 222, p. 146). 